$10-1-2012$

\title{
COX Inhibitors Indomethacin and Sulindac Derivatives as Antiproliferative Agents: Synthesis, Biological Evaluation, and Mechanism Investigation
}

\author{
Snigdha Chennamaneni \\ Cleveland State University \\ Bo Zhong \\ Cleveland State University \\ Rati Lama \\ Cleveland State University \\ Bin Su \\ Cleveland State University, B.SU@csuohio.edu
}

Follow this and additional works at: https://engagedscholarship.csuohio.edu/scichem_facpub

Part of the Chemistry Commons

How does access to this work benefit you? Let us know!

\section{Recommended Citation}

Chennamaneni, Snigdha; Zhong, Bo; Lama, Rati; and Su, Bin, "COX Inhibitors Indomethacin and Sulindac Derivatives as Antiproliferative Agents: Synthesis, Biological Evaluation, and Mechanism Investigation" (2012). Chemistry Faculty Publications. 381.

https://engagedscholarship.csuohio.edu/scichem_facpub/381

This Article is brought to you for free and open access by the Chemistry Department at EngagedScholarship@CSU. It has been accepted for inclusion in Chemistry Faculty Publications by an authorized administrator of EngagedScholarship@CSU. For more information, please contact library.es@csuohio.edu. 


\title{
4-Hydroxyphenylretinamide (4HPR) derivatives regulate aromatase activity and expression in breast cancer cells
}

\author{
Bin Su , Serena M. Mershon, Laura A. Stonerock, \\ Robert W. Curley Jr., Robert W. Brueggemeier
}

\begin{abstract}
Introduction
4-Hydroxyphenylretinamide (4HPR) is one of the most studied retinoid analogs for use in cancer prevention. It is found to inhibit the growth of breast, prostate, and ovarian cancers in animal models [1-5]. 4HPR has potent preventive effects in a rodent mammary tumor model and less toxicity than retinoic acid, and has been tested in a large breast cancer prevention trial [6]. Retinoids bind to retinoic acid receptors (RAR) and retinoid $\mathrm{X}$ receptors (RXR), which bind to specific DNA sequences to regulate gene expression [7]. However, as a synthetic retinoid analog, 4HPR minimally binds RXR receptors and seems to have only moderate affinity for both the RAR $\beta$ and RAR $\gamma$ receptor compared to all-trans retinoic acid (RA) [8,9]. This result points to a mode of action of 4HPR that is at least partially independent of the RAR or RXR. So far, a definitive mechanism by which 4HPR exerts its chemo-preventive effect on mammary tumor growth remains unclear.
\end{abstract}

Approximately, two-thirds of breast cancers are termed hormone-dependent breast cancers, contain estrogen receptors (ER), and require estrogen for tumor growth. Aromatase activity in tumor or surrounding tissue plays a significant role in promoting this type of tumor growth due to the local production of estrogen, and thus aromatase is an important target in the treatment of ER positive breast cancer [10]. Recently, there are several studies reporting that 4HPR inhibits both the expression and enzyme activity of aromatase in breast cancer cells and placental cells $[11,12]$. In addition, RA can induce aromatase activity in breast cancer and placental cells at the transcriptional level $[13,14]$. This induction apparently is from the RA agonist effect with RAR and RXR. We hypothesize that investigation of RA and 4HPR analogs might discover potent RAR antagonist which can effectively down regulate aromatase activity and expression in breast cancer cells.

A number of these analogs were synthesized (Fig. 1) and investigated in breast cancer cells and also a microsomal aromatase enzyme assay. In addition, CYP19 gene expression in breast cancer cells was checked after the treatment with the 4HPR analogs. Unexpectedly, some of the derivatives dramatically up regulated aromatase activity and expression in several breast cancer cell lines. Only one analog significantly decreased aromatase activity in all three breast cancer cell lines tested. To 


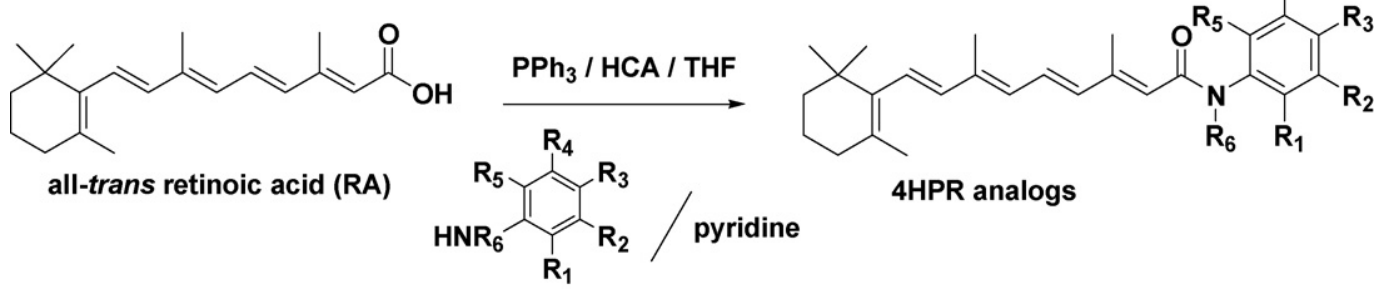

Fig. 1. Synthesis of 4HPR analogs [15].

our surprise, 4HPR decreased aromatase activity in a cell selective manner and only slightly inhibited microsomal aromatase activity in our studies.

\section{Materials and methods}

\section{Reagents}

Radiolabeled $\left[1 \beta-{ }^{3} \mathrm{H}\right]$-androst-4-ene-3,17-dione was obtained from NEN Life Science Products (Boston, MA). 4HPR and analogs were synthesized according to the published procedure [15]. For in vitro experiments, these agents at various concentrations were dissolved in DMSO. Trypsin, TRIzol, and all enzymes were obtained from Invitrogen (Carlsbad, CA). Radioactive samples were counted on a LS6800 liquid scintillation counter (Beckman, Palo Alto, CA). Scintillation solution 3a70B was obtained from Research Prospect International Corp. (Mount Prospect, IL). ( \pm )-Aminoglutethimide (AG), NADP ${ }^{+}$ and glucose-6-phosphate dehydrogenase were purchased from Sigma (St. Louis, MO). Human tissue (placenta) was obtained through OSUCCC Tissue Procurement under IRB-approved protocols OSU\#2002H0105.

\section{Cell culture}

SK-BR-3, MCF-7 and MDA-MB-231 cells were obtained from ATCC (Rockville, MD). Cell cultures were maintained in phenol red-free custom media (MEM, Earle's salts, $1.5 \times$ amino acids, $2 \times$ non-essential amino acids, L-glutamine, $1.5 \times$ vitamins, Gibco BRL) supplemented with $10 \%$ fetal bovine serum (FBS), $2 \mathrm{mM}$ L-glutamine and $20 \mathrm{mg} / \mathrm{L}$ gentamycin. FBS was heat inactivated for $30 \mathrm{~min}$ in a $56^{\circ} \mathrm{C}$ water bath before use. Cell cultures were grown at $37^{\circ} \mathrm{C}$, in a humidified atmosphere of $5 \% \mathrm{CO}_{2}$ in a Hereaus $\mathrm{CO}_{2}$ incubator. For all experiments, cells were plated in either T-25 flasks or $100 \mathrm{~mm}$ plates and grown to subconfluency before treatment.

\section{Tritiated water-release assay in cells}

Measurement of aromatase enzyme activity in cells was based on the tritium water-release assay [16]. Cells in T-25 flasks or $100 \mathrm{~mm}$ plates were treated with DMSO (control), $4 \mathrm{HPR}$ and analogs for $24 \mathrm{~h}$. Cells were then incubated for $6 \mathrm{~h}$ with fresh media containing drugs and $2 \mu \mathrm{Ci}\left[1 \beta-{ }^{3} \mathrm{H}\right]-$ androst-4-ene-3,17-dione (100 nM). Subsequently, the reaction mixture was removed, and proteins were precipitated using $10 \%$ trichloroacetic acid at $42^{\circ} \mathrm{C}$ for $20 \mathrm{~min}$. After a brief centrifugation, the media was extracted three times with an equal amount of chloroform to extract unused substrate, and the aqueous layer subsequently treated with $1 \%$ dextran-treated charcoal. After centrifugation, a $250-\mu \mathrm{L}$ aliquot containing the product was counted in $5 \mathrm{~mL}$ of liquid scintillation mixture. Each sample was run in triplicate and results were corrected for blanks and for the cell contents of culture flasks. Results were expressed as picomoles of ${ }^{3} \mathrm{H}_{2} \mathrm{O}$ formed per hour incubation time per million cells ( $\mathrm{pmol} / \mathrm{h} / 10^{6}$ cells). To determine the amount of live cells in each flask, the cells were trypsinized and analyzed using the diphenylamine DNA assay adapted to a 96-well plate.

\section{Cell viability analysis}

The effect of 4HPR derivatives on breast cancer cell viability was assessed by using the 3-(4,5-dimethylthiazol-2-yl)-2,5diphenyl- $2 H$-tetrazolium bromide assay in six replicates. Cells were grown in custom media in 96-well, flat-bottomed plates for $24 \mathrm{~h}$, and were exposed to various concentrations of 4HPR derivatives dissolved in DMSO (final concentration $\leq 0.1 \%$ ) in culture media for $24 \mathrm{~h}$. Controls received DMSO vehicle at a concentration equal to that in drug-treated cells. The medium was removed, replaced by $200 \mu \mathrm{L}$ of $0.5 \mathrm{mg} / \mathrm{mL}$ of $3-(4,5-$ dimethylthiazol-2-yl)-2,5-diphenyl-2H-tetrazolium bromide in fresh media, and cells were incubated in the $\mathrm{CO}_{2}$ incubator at $37^{\circ} \mathrm{C}$ for $2 \mathrm{~h}$. Supernatants were removed from the wells, and the reduced 3-(4,5-dimethylthiazol-2-yl)-2,5-diphenyl- $2 \mathrm{H}$ tetrazolium bromide dye was solubilized in $200 \mu \mathrm{L} /$ well DMSO. Absorbance at $570 \mathrm{~nm}$ was determined on a plate reader.

\section{Preparation of human placental microsomes}

Human placenta was processed immediately after delivery from The Ohio State University Hospitals at $4{ }^{\circ} \mathrm{C}$. The placenta was washed with normal saline, and connective and vascular tissue was removed. Microsomes were prepared from the remaining tissue using the method developed in our laboratory. Microsomal suspensions were stored at $-80^{\circ} \mathrm{C}$ until required.

\section{Tritiated water-release assay with human placental} microsomes

Inhibition of human placental aromatase was determined by monitoring the amount of tritiated water released as the 
enzyme converts $[1 \beta-3 \mathrm{H}]$ androst-4-ene-3,17-dione to estrone [17]. Aromatase activity assays were carried in $0.1 \mathrm{M}$ potassium phosphate buffer ( $\mathrm{pH} 7.0$ ) with 5\% propylene glycol. All samples contained a NADPH regenerating system consisting of $2.85 \mathrm{mM}$ glucose-6-phosphate, $1.8 \mathrm{mM} \mathrm{NADP}+$ and 1.5 units of glucose-6-phosphate dehydrogenase. Samples contained $100 \mathrm{nM}$ androst-4-ene-3, 17-dione (400,000-450,000 dpm). Reactions were initiated with the addition of $50 \mu \mathrm{g}$ microsomal protein. The total incubation volume was $2.0 \mathrm{~mL}$. Incubations were allowed to proceed for $15 \mathrm{~min}$ in a shaking water bath at $37^{\circ} \mathrm{C}$. Reactions were quenched by the addition of $2.0 \mathrm{~mL}$ of chloroform. Samples were then vortexed and centrifuged for $5 \mathrm{~min}$ and the aqueous layer was removed. The aqueous layer was subsequently extracted twice in the same manner with $2.0 \mathrm{~mL}$ chloroform. A $0.5 \mathrm{~mL}$ aliquot of the final aqueous layer was combined with $5 \mathrm{~mL}$ 3a70B scintillation cocktail and the amount of radioactivity was determined. Each sample was run in triplicate and background values were determined with microsomal protein inactivated by boiling.

\section{RNA extraction}

Total RNA was isolated using the TRIzol reagent according to the manufacturer's protocol. Total RNA pellets were dissolved in DNase, RNase-free water and quantitated using a spectrophotometer. The quality of RNA samples was determined by electrophoresis through agarose gels and staining with ethidium bromide; the $18 \mathrm{~S}$ and $28 \mathrm{~S}$ rRNA bands were visualized under ultraviolet light.

\section{cDNA synthesis}

Isolated total RNA $(2 \mu \mathrm{g})$ was treated with DNase I Amplification grade, according to the recommended protocol to eliminate any DNA before reverse transcription. Treated total RNA was denatured at $65^{\circ} \mathrm{C}$ for $5 \mathrm{~min}$ in the presence of $2.5 \mathrm{ng} / \mu \mathrm{L}$ random hexamers and $0.5 \mathrm{mM}$ dNTP mix. The samples were snap-cooled on ice and centrifuged briefly. Complementary DNA (cDNA) was synthesized using Superscript II reverse transcriptase according to the recommended protocol. Briefly, the reactions were conducted in the presence of $1 \times$ First-Strand Buffer and $20 \mathrm{mMDTT}$ at $42^{\circ} \mathrm{C}$ for $50 \mathrm{~min}$ and consequently inactivated at $70^{\circ} \mathrm{C}$ for $15 \mathrm{~min}$. The cDNA generated was used as a template in real-time PCR reactions.

\section{Real-time PCR with Taqman assay}

Real-time PCR was performed using the Opticon ${ }^{\mathrm{TM}} 2$ system from MJ Research (Waltham, MA). For the CYP19 total gene the PCR reaction mixture consisted of Taqman ${ }^{\circledR}$ Universal PCR Master Mix (Applied Biosystems), $600 \mathrm{nM}$ of CYP19 primer (sense: $5^{\prime}$-TGT CTC TTT GTT CTT CAT GCT ATT TCT C-3'; antisense: 5'-TCA CCA ATA ACA GTC TGG ATT TCC-3'); $250 \mathrm{nM}$ Taqman probe (6FAM 5'-TGC AAA GCA CCC TAA TGT TGA AGA GGC AAT-3'TAMRA) (Invitrogen), and $2.0 \mu \mathrm{L}$ of each cDNA sample in a final volume of $20 \mu \mathrm{L}$. For the $18 \mathrm{~S}$ house keeping total gene the PCR reac- tion mixture consisted of Taqman ${ }^{\circledR}$ Universal PCR Master Mix (Applied Biosystems), $500 \mathrm{nM}$ of $18 \mathrm{~S}$ primer (sense: $5^{\prime}-\mathrm{CAG}$ TTC ATA CAG CGG AAC ACT G-3'; antisense: $5^{\prime}$-TTT GCT GGA GAA CAG GGC TG-3'); $50 \mathrm{nM}$ Taqman probe (6FAM $5^{\prime}$-TGC TGG CAC CAG ACT TGC CCT C-3'TAMRA) (Invitrogen), and $2.0 \mu \mathrm{L}$ of each cDNA sample in a final volume of $20 \mu \mathrm{L}$. The Taqman probes for aromatase and $18 \mathrm{~S}$ were designed to anneal to a specific sequence of the aromatase and $18 \mathrm{~S}$ gene correspondingly between the forward and the reverse primers. Cycling conditions were $50^{\circ} \mathrm{C}$ for $2 \mathrm{~min}$ and $95^{\circ} \mathrm{C}$ for $10 \mathrm{~min}$, followed by 50 cycles at $95^{\circ} \mathrm{C}$ for $15 \mathrm{~s}$ and $60^{\circ} \mathrm{C}$ for $1 \mathrm{~min}$.

\section{Statistical analysis}

Statistical and graphical information was determined using GraphPad Prism software (GraphPad Software Incorporated) and Microsoft Excel (Microsoft Corporation). Determination of $\mathrm{IC}_{50}$ values were performed using nonlinear regression analysis. Statistically significant differences were calculated with the two-tailed unpaired Student's $t$-test and $p$ values reported at $95 \%$ confidence intervals.

\section{Results}

\section{HPR analogs regulate aromatase activity in $S K-B R-3$ breast cancer cells}

4HPR decreases both microsomal aromatase and cellular aromatase activity [11]. We propose that 4HPR analogs might be more effective in suppression of aromatase. A $5 \mu \mathrm{M}$ aromatase screening assay in SK-BR-3 breast cancer cells was performed with these compounds. Unfortunately, most of the derivatives and even 4HPR itself did not decrease aromatase activity in SK-BR-3 breast cancer cells (Table 1). Only compound 19 significantly suppressed aromatase activity. To our surprise, two analogs (compounds $\mathbf{7 , 2 0}$ ) dramatically stimulate cellular aromatase activity, which is similar to RA [13]. Though 4HPR binds to retinoic acid receptors very weakly, we hypothesize that these two 4HPR analogs might bind to retinoic acid receptors as agonist to stimulate aromatase expression. Further studies confirmed that both the stimulation and suppression of aromatase occur dose dependently (Fig. 2A) and the agents tested in the assays do not cause any cell cytotoxicity which rule out the possibility that compound $\mathbf{1 9}$ decreases cellular aromatase activity because of cytotoxic effect (Fig. 2B).

4HPR analogs regulate aromatase activity in MCF-7 and MDA-MB-231 breast cancer cells

Although 4HPR did not affect aromatase in SK-BR-3 cells, it and compound 19 significantly decreased aromatase activity in MCF-7 breast cancer cells (Fig. 3A). However, 4HPR at $5 \mu \mathrm{M}$ caused significant cell cytotoxicity (Fig. 3B), and part of the suppression of aromatase activity might come from the cytotoxic effect. Compounds 7, 20 and RA all significantly induced cellular aromatase activity (Fig. 3A) and did not cause cell cytotoxicity. 
Table 1

4HPR analogs regulate aromatase activity in SK-BR-3 breast cancer cells

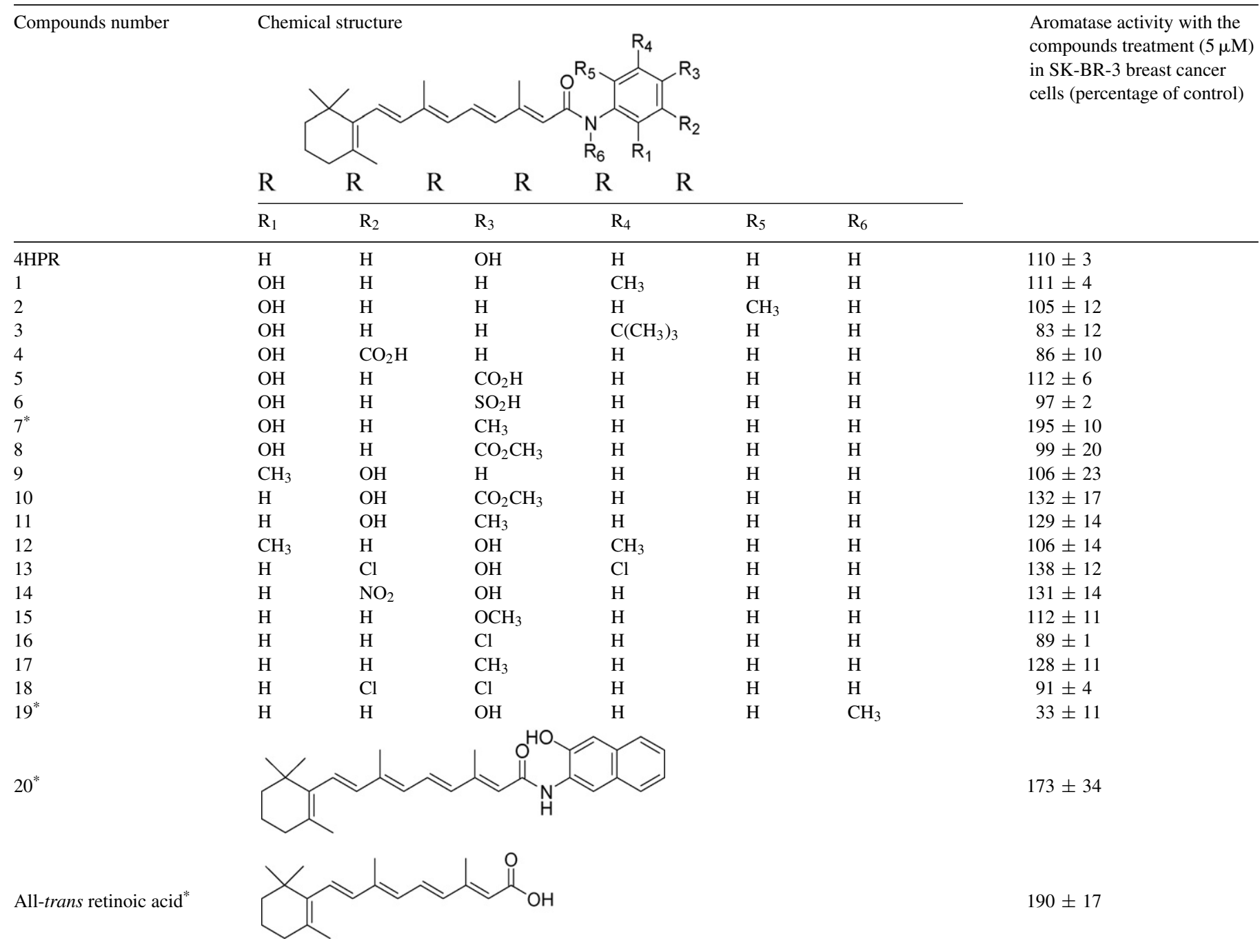

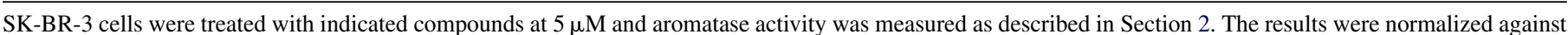

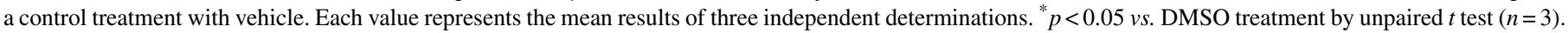

In addition, the effect of these agents on aromatase occurred in the similar trend in MDA-MB-231 breast cancer cells and they did not cause any cell cytotoxicity (Fig. 4). However, the suppression of aromatase activity by compound 19 in MDAMB-231 cells was not as significant as it in SK-BR-3 and MCF-7 breast cancer cells (Fig. 4). We think that low aromatase activity in MDA-MB-231 cells may be one of the reasons, because the suppression effect cannot be clearly observed with the low enzyme activity.

\section{HPR decrease microsomal aromatase activity}

It has been reported that 4HPR inhibits microsomal aromatase extracted from JAR cells [12]. We did the study with placenta microsomal aromatase and found that 4HPR does directly inhibit enzyme activity. This may also be one of the mechanisms by which 4HPR suppresses aromatase activity in MCF-7 cells. However, compound $\mathbf{1 9}$ did not inhibit aromatase enzyme activity at all although it has very similar structure to 4HPR (Fig. 5), which suggests that compound 19 does not directly inhibit cellular aromatase activity.

\section{Compound 7, 20 and RA stimulate CYP19 gene} expression

Since compound 7, 20 and RA all induce aromatase activity in the three breast cancer cell lines tested and it has been reported that RA stimulates $C Y P 19$ gene expression in placental cells [13], we hypothesized that compound 7, 20 and RA might stimulate aromatase expression in breast cancer cells as well. Investigations found that compound 7, 20 and RA all induced CYP19 gene expression in these three breast cancer cell lines (Fig. 6), although some results are not statistically significant. This is consistent with the cellular aromatase assay results.

4HPR did not affect aromatase expression in any of the cell studied. Although compound 19 significantly decreased 

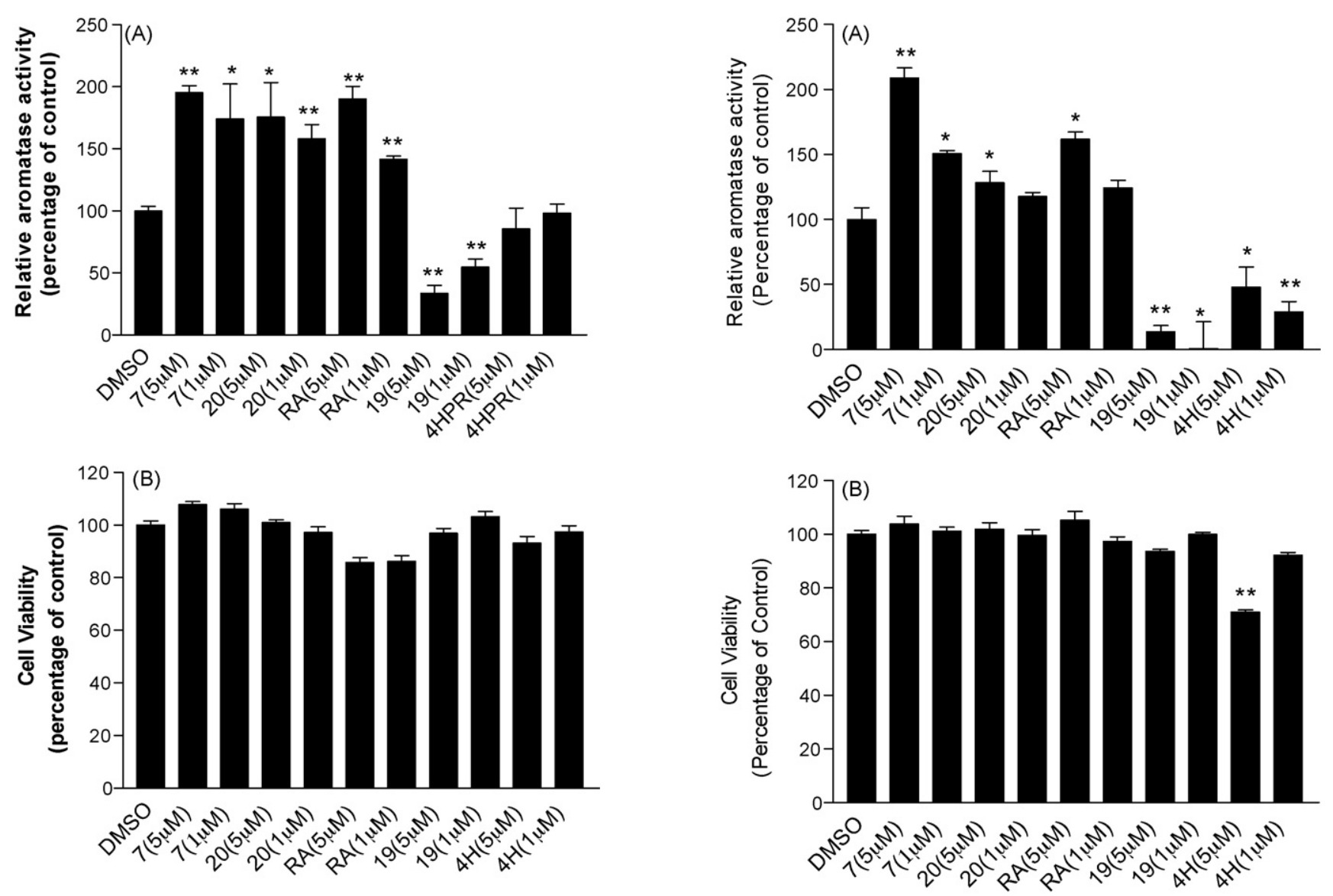

Fig. 2. 4HPR analogs and RA regulate aromatase activity in SK-BR-3 cells in a dose dependent manner, no cytotoxic effect was observed. (A) Aromatase study: SK-BR-3 cells were treated with indicated compounds at indicated concentrations and aromatase activity was measured as described in Section $2 .{ }^{*} p<0.05$, ${ }^{* *} p<0.005 v s$. DMSO treatment by unpaired $t$ test $(n=3)$. (B) Cell cytotoxicity study: SK-BR-3 cells were treated with indicated compounds at indicated concentrations and cell viability was measured by MTT assay as described in Section 2.

aromatase activity in all three breast cancer cell lines, it only suppresses CYP19 gene expression in MCF-7 cells (Fig. 6B). Since it does not directly inhibit aromatase enzyme activity (Fig. 5), we propose that compound $\mathbf{1 9}$ might suppress cellular aromatase with a post transcriptional mechanism. This can explain that it decreases aromatase activity in MDA-MB-231 and SK-BR3 cells without suppression of their CYP19 gene expression. Due to the double mechanisms in MCF-7 cells, compound 19 is very potent in suppression of aromatase activity in this cell line (Fig. 3A).

\section{Discussion}

Retinoids are natural and synthetic analogs of vitamin A that are involved in the regulation of many biological functions such as cellular differentiation and proliferation. RA and 4HPR are considered potential drug candidates for treatment and prevention of several cancers and 4HPR is less toxic than RA. Aromatase represents a novel target for the potential therapeutic actions of $4 \mathrm{HPR}$ in ER positive breast cancer treatment from recent studies $[11,12]$.

Fig. 3. 4HPR analogs and RA regulate aromatase activity in MCF-7 cells in a dose dependent manner, no cytotoxic effect was observed. (A) Aromatase study: MCF-7 cells were treated with indicated compounds at indicated concentrations and aromatase activity was measured as described in Section $2 .{ }^{*} p<0.05$, ${ }^{* * *} p<0.005 v s$. DMSO treatment by unpaired $t$ test $(n=3)$. (B) Cell cytotoxicity study: MCF-7 cells were treated with indicated compounds at indicated concentrations and cell viability was measured by MTT assay as described in Section 2 . ${ }^{* *} p<0.005 v s$. DMSO treatment by unpaired $t$ test $(n=6)$.

Unfortunately, most 4HPR derivatives used in this study do not suppress aromatase activity in breast cancer cells. In fact, two compounds (7 and $\mathbf{2 0}$ ) significantly induced aromatase activity in all three cell lines. Further studies exhibit that compound 7 and 20 also stimulate $C Y P 19$ gene expression in these cells. It has been well studied that RA is a potent retinoic acid receptor agonist and stimulates aromatase expression in placental cells [8,13]. In addition, other RXR and RAR ligands dramatically stimulate aromatase in MCF-7 breast cancer cells [14], which proves that the retinoic acid receptor plays an important role in regulating aromatase expression in breast cancer cells. Our studies further confirm that the retinoic acid receptor agonist RA stimulates aromatase expression in these three breast cancer cell lines. Due to the fact that compound $\mathbf{7}$ and $\mathbf{2 0}$ stimulated aromatase expression in breast cancer cells which is similar to RA, we propose that these two compounds may also bind to retinoic receptor as agonist. Further studies are needed to quantify the binding affinity of compound $\mathbf{7}$ and $\mathbf{2 0}$ with retinoic receptors.

Interestingly, 4HPR only decreased aromatase activity in MCF-7 breast cancer cells in our study. It has been also reported 

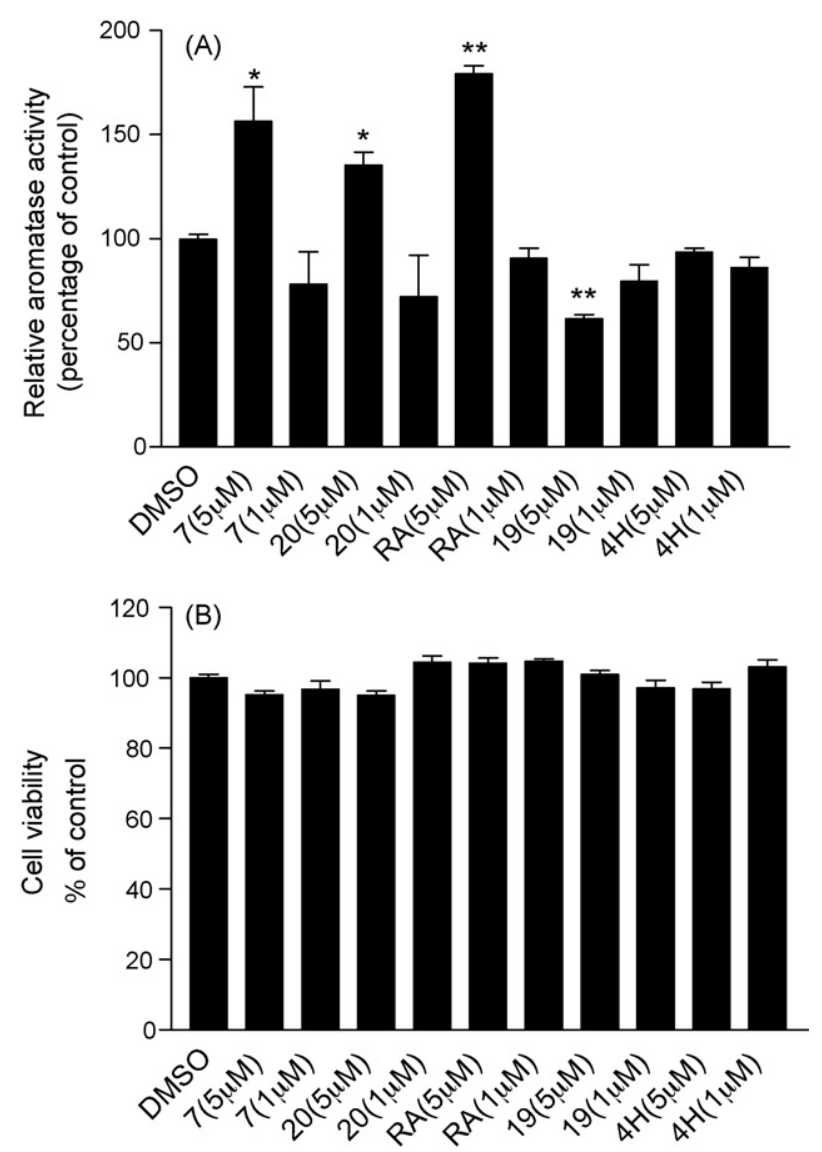

Fig. 4. 4HPR analogs and RA regulate aromatase activity in MDA-MB-231 cells in a dose dependent manner, no cytotoxic effect was observed. (A) Aromatase study: MDA-MB-231 cells were treated with indicated compounds at indicated concentrations and aromatase activity was measured as described in Section 2. ${ }^{*} p<0.05,{ }^{* *} p<0.005 v s$. DMSO treatment by unpaired $t$ test $(n=3)$. (B) Cell cytotoxicity study: MDA-MB-231 cells were treated with indicated compounds at indicated concentrations and cell viability was measured by MTT assay as described in Section 2.

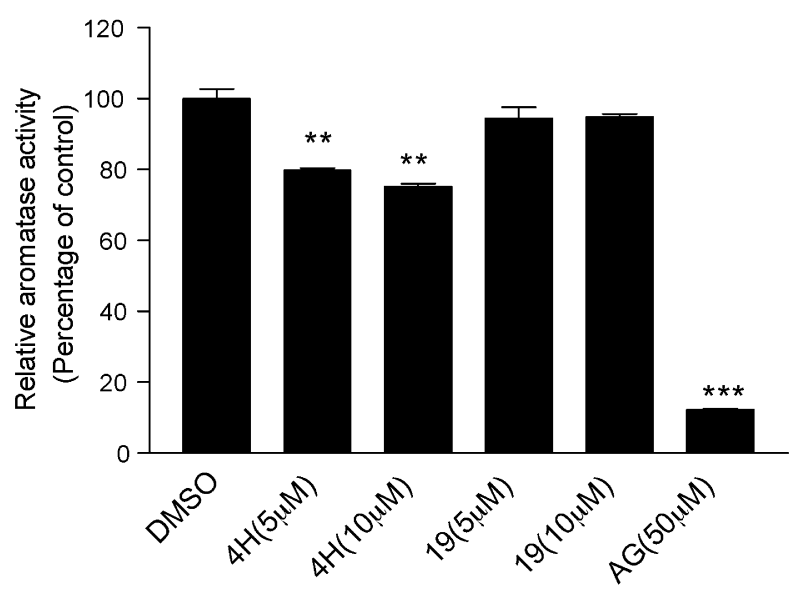

Fig. 5. Inhibition of microsomal aromatase activities by 4HPR and compound19. Each data bar represents the mean results of three independent determinations. Error bars represent standard error. AG is used as a positive control. ${ }^{* *} p<0.005,{ }^{* * * *} p<0.0001 v s$. DMSO treatment by unpaired $t$ test $(n=3)$.
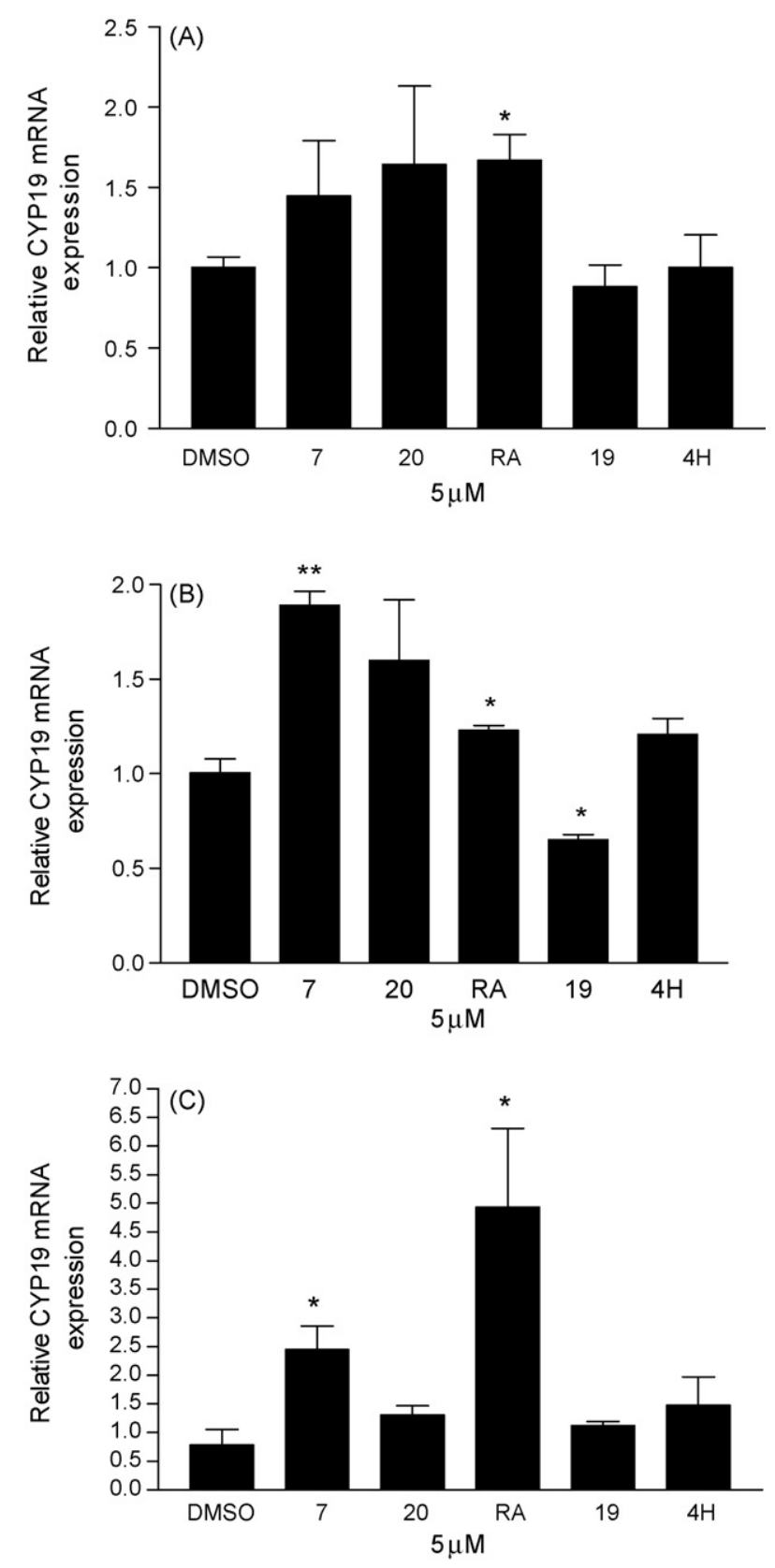

Fig. 6. Real-time RT-PCR analysis of CYP19 mRNA expression in SK-BR-3, MCF-7 and MDA-MB-231 cells after treatment with the agents. (A) SK-BR-3 cells, (B) MCF-7 cells and (C) MDA-MB-231 cells. Cells were treated for $24 \mathrm{~h}$ with the test agents at $5 \mu \mathrm{M}$, and total RNA was isolated. Results are expressed as means of $C Y P 19$ (normalized to $18 \mathrm{~S}$ rRNA) \pm SEM. ${ }^{*} p<0.05 v s$. control by unpaired $t$ test $(n=3)$.

that 4HPR suppresses aromatase in JEG-3 placental cells, which is accomplished with ceramide increase. However, it does not affect aromatase induced by dexamethasone and cholera toxin in MDA-MB-231 cells [12]. The signalling molecule ceramide has also been previously implicated as a negative regulator of aromatase activity [18]. The result demonstrates that 4HPR may suppress aromatase activity in a cell selective manner via ceramide by a receptor independent mechanism. This has been further proved by another study in MCF-7 cells in which 4HPR 
decreases cellular aromatase activity without affecting CYP19 gene expression at the same concentration [11].

Compound 19 suppresses aromatase activity in all three breast cancer cell lines without direct enzyme inhibition. The results suggest that this compound suppresses cellular aromatase activity mainly via a non-genomic mechanism, though it also decreases CYP19 gene expression in MCF-7 cells. Besides direct inhibition, agents that target protein phosphorylation also decrease cellular aromatase activity in bone, brain, and breast cancer cells in a rapid non-genomic mechanism [19-21]. It has been reported that the PI3 kinase (PI3K) inhibitor LY294002 and mitogen-activated protein kinase (MAPK) inhibitor U0126 decrease aromatase activity by blocking the cell phosphorylation pathways without affecting CYP19 gene expression [21]. This could be a possible mechanism that compound 19 decreases cellular aromatase activity with a non-genomic action. Further work is needed to search for the molecular target(s) of compound 19. However, the dual functions in suppressing aromatase in MCF-7 cell line make this compound a good lead to design more effect agents to target aromatase.

\section{Acknowledgements}

This work was supported by the National Institutes of Health (NIH) Grant R01 CA73698 (to R.W.B.), CA49837 (to R.W.C., Jr.), and The Ohio State University Comprehensive Cancer Center Breast Cancer Research Fund.

\section{References}

[1] K. Dowlatshahi, R.G. Mehta, C.F. Thomas, N.M. Dinger, R.C. Moon, Therapeutic effect of $\mathrm{N}$-(4-hydroxyphenyl)retinamide on $\mathrm{N}$-methyl- $\mathrm{N}$ nitrosourea-induced rat mammary cancer, Cancer Lett. 47 (1989) 187-192.

[2] F. Formelli, L. Cleris, Synthetic retinoid fenretinide is effective against a human ovarian carcinoma xenograft and potentiates cisplatin activity, Cancer Res. 53 (1993) 5374-5376.

[3] R.C. Moon, J.F. Pritchard, R.G. Mehta, C.T. Nomides, C.F. Thomas, N.M. Dinger, Suppression of rat mammary cancer development by $\mathrm{N}$ (4-hydroxyphenyl)retinamide (4-HPR) following surgical removal of first palpable tumor, Carcinogenesis 10 (1989) 1645-1649.

[4] M. Pollard, P.H. Luckert, The inhibitory effect of 4-hydroxyphenyl retinamide (4-HPR) on metastasis of prostate adenocarcinoma-III cells in Lobund-Wistar rats, Cancer Lett. 59 (1991) 159-163.

[5] M.B. Sporn, N. Suh, Chemoprevention: an essential approach to controlling cancer, Nat. Rev. Cancer 2 (2002) 537-543.

[6] A. Costa, F. Formelli, F. Chiesa, A. Decensi, G. De Palo, U. Veronesi, Prospects of chemoprevention of human cancers with the synthetic retinoid fenretinide, Cancer Res. 54 (1994) 2032s-2037s
[7] H.S. Ahuja, A. Szanto, L. Nagy, P.J. Davies, The retinoid X receptor and its ligands: versatile regulators of metabolic function, cell differentiation and cell death, J. Biol. Regul. Homeost. Agents 17 (2003) $29-45$.

[8] J.R. Walker, G. Alshafie, N. Nieves, J. Ahrens, M. Clagett-Dame, H. AbouIssa, R.W. Curley Jr., Synthesis and preliminary chemotherapeutic evaluation of the fully C-linked glucuronide of $\mathrm{N}$-(4-hydroxyphenyl)retinamide, Bioorg. Med. Chem. 14 (2006) 3038-3048.

[9] B.P. Sani, Y.F. Shealy, D.L. Hill, N-(4-Hydroxyphenyl)retinamide: interactions with retinoid-binding proteins/receptors, Carcinogenesis 16 (1995) 2531-2534

[10] R.W. Brueggemeier, J.C. Hackett, E.S. Diaz-Cruz, Aromatase inhibitors in the treatment of breast cancer, Endocr. Rev. 26 (2005) 331-345.

[11] H.P. Ciolino, T.T. Wang, N. Sathyamoorthy, Inhibition of aromatase activity and expression in MCF-7 cells by the chemopreventive retinoid $\mathrm{N}$-(4hydroxy-phenyl)-retinamide, Br. J. Cancer 83 (2000) 333-337.

[12] W.J. Andrews, G. Winnett, F. Rehman, P. Shanmugasundaram, D. Hagen, M.P. Schrey, Aromatase inhibition by 15-deoxy-prostaglandin J(2) (15$\mathrm{dPGJ}(2)$ ) and $\mathrm{N}$-(4-hydroxyphenyl)-retinamide (4HPR) is associated with enhanced ceramide production, J. Steroid Biochem. Mol. Biol. 94 (2005) 159-165.

[13] S.J. Zhu, Y. Li, H. Li, Y.L. Wang, Z.J. Xiao, P. Vihko, Y.S. Piao, Retinoic acids promote the action of aromatase and 17beta-hydroxysteroid dehydrogenase type 1 on the biosynthesis of 17 beta-estradiol in placental cells, J. Endocrinol. 172 (2002) 31-43.

[14] Y.M. Mu, T. Yanase, Y. Nishi, N. Hirase, K. Goto, R. Takayanagi, H. Nawata, A nuclear receptor system constituted by RAR and RXR induces aromatase activity in MCF-7 human breast cancer cells, Mol. Cell Endocrinol. 166 (2000) 137-145.

[15] S.M. Mershon, A.L. Anding, J.S. Chapman, M. Clagett-Dame, L.A. Stonerock, R.W. Curley Jr., Solid phase-assisted synthesis and screening of a small library of $N$-(4-hydroxyphenyl)retinamide (4-HPR) analogs, Bioorg. Med. Chem. Lett. 17 (2007) 836-840.

[16] J.A. Richards, R.W. Brueggemeier, Prostaglandin E2 regulates aromatase activity and expression in human adipose stromal cells via two distinct receptor subtypes, J. Clin. Endocrinol. Metab. 88 (2003) 2810-2816.

[17] B. Su, J.C. Hackett, E.S. Diaz-Cruz, Y.W. Kim, R.W. Brueggemeier Lead optimization of 7-benzyloxy 2-(4'-pyridylmethyl)thio isoflavone aromatase inhibitors, Bioorg. Med. Chem. 13 (2005) 6571-6577.

[18] P. Santana, L. Llanes, I. Hernandez, G. Gallardo, J. Quintana, J. Gonzalez, F. Estevez, d.G. Ruiz, L.F. Fanjul, Ceramide mediates tumor necrosis factor effects on P450-aromatase activity in cultured granulosa cells, Endocrinology 136 (1995) 2345-2348.

[19] J. Balthazart, M. Baillien, T.D. Charlier, G.F. Ball, Calcium-dependent phosphorylation processes control brain aromatase in quail, Eur. J. Neurosci. 17 (2003) 1591-1606.

[20] J. Balthazart, M. Baillien, T.D. Charlier, C.A. Cornil, G.F. Ball, Multiple mechanisms control brain aromatase activity at the genomic and non-genomic level, J. Steroid Biochem. Mol. Biol. 86 (2003) 367-379.

[21] W. Yue, J.P. Wang, M.R. Conaway, Y. Li, R.J. Santen, Adaptive hypersensitivity following long-term estrogen deprivation: involvement of multiple signal pathways, J. Steroid Biochem. Mol. Biol. 86 (2003) 265-274. 